\title{
The Global Problem of the Antibiotic and Heavy Metal Resistance in Aquatic Resources: An Examination of Gelevera Creek (Giresun), Turkey ${ }^{\left[{ }^{*}\right]}$
}

\author{
Hakan IŞIK ${ }^{1 *}$ Tamer AKKAN ${ }^{2}$ \\ ${ }^{1}$ Giresun University, Natural Sciences Institutes, Biology Division, Giresun, Turkey \\ ${ }^{2}$ Giresun University, Science and Art Faculty, Biology Department, Giresun, Turkey
}

How to cite: Işık, H. \& Akkan, T. (2021). The Global Problem of the Antibiotic and Heavy Metal Resistance in Aquatic Resources; An examination of Gelevera Creek (Giresun), Turkey. J. Anatolian Env. and Anim. Sciences, 6(3), 382-389.

Atıf yapmak için: Işık, H. \& Akkan, T. (2021). Su Kaynaklarında Antibiyotik ve Ağır Metal Direncinin Küresel Sorunu; Gelevera Deresi’nin İncelemesi (Giresun), Türkiye. Anadolu Çev. ve Hay. Dergisi, 6(3), 382-389.

https://orcid.org/0000-0002-9907-9315

(iD : https://orcid.org/0000-0002-9866-4475

*Corresponding author's:

Hakan IŞIK

Giresun University, , Natural Sciences

Institutes, Biology Division, Giresun, Turkey

凶: hknbiyoo@gmail.com

\begin{abstract}
Gelevera Creek was chosen as the sample area in this study, which aims to detect antibiotic and heavy metal resistance in water resources that threaten human, animal and ecosystem health on a global scale. For this purpose, surface water and sediment were collected monthly from four different stations starting from April 2017 and ending in March 2018. After the Gr (-) and Gr (+) bacteria isolation in selective media, the 325 isolated were tested for their resistance against 4 different heavy metals. The resistance levels of these bacteria against to cadmium, copper, lead and manganese resistance were detected respectively as $89 \%$, $60.16 \%, 33 \%, 29.8 \%(\mathrm{Cd}>\mathrm{Cu}>\mathrm{Pb}>\mathrm{Mn})$. The 82 isolates with high resistance against heavy metals in each station were also tested for their resistance against antibiotics. The levels of resistance against antibiotics of these isolated strains were found respectively as follows: cefazolin: $69.6 \%$, cefuroxime: $59.4 \%$, nalidixic acid: $51.7 \%$, ampicillin: $46 \%$, cefotaxime: $39.1 \%$, meropenem: $31.4 \%$, amikacin: $21.7 \%$, erythromycin: $13 \%$, and chloramphenicol: $3.3 \%$. In our study, two isolates with high antibiotic and heavy metal, using the Vitek-II Compact System were identified as Serratia marcenscens (99\%) and Enterococcus avium (91\%). Furthermore, the multiple antibiotic resistance levels (MAR) of all isolates are $80,5 \%$. The results indicate that the isolates taken from the Gelevera Creek (Giresun) were found to be extremely resistant against commercially used antibiotics and heavy metals, and this shows that there is antibiotic and heavy metal contamination in drinking water reserves.
\end{abstract}

Keywords: Antibiotic, Gelevera Creek, Giresun, Heavy Metal, Resistance.

\section{Su Kaynaklarında Antibiyotik ve Ağır Metal Direncinin Küresel Sorunu: Gelevera Deresi'nin İncelemesi (Giresun, Türkiye)}

\section{*Sorumlu yazar:}

Hakan IȘIK

Giresun Üniversitesi, Fen Bilimleri Enstitüsü,

Biyoloji Anabilim Dalı, Giresun, Türkiye

凶: hknbiyoo@gmail.com
Öz: Küresel boyutta mevcut olan, insan, hayvan ve ekosistem sağlığını tehdit eden antibiyotik ve ağır metal direncinin su kaynaklarında tespitinin amaç edinildiği bu çalışmada örnek alan olarak Gelevera Deresi seçilmiştir. Bu amaçla, Gelevera Deresi'ndeki dört istasyondan alınan yüzey suyu ve sediment örnekleri Nisan 2017-Mart 2018'a kadar aylık olarak toplanmıştır. Seçici bir şekilde Gr (-) ve Gr (+) bakteri izolasyonun ardından izole edilmiş olan 325 bakterinin 4 farklı ağır metale karşı direnç düzeyleri tespit edilmiştir. Bu izolatların kadminyum, bakır, kurşun ve manganese karşı direnç düzeyleri \% ifadesiyle sırasıyla; \%89; $\% 60,16 ; \% 33 ; \% 29,8(\mathrm{Cd}>\mathrm{Cu}>\mathrm{Pb}>\mathrm{Mn})$ olarak tespit edilmiştir. Her bir istasyonda ağır metal direnç düzeyleri yüksek olan izolatların ilaveten antibiyotik direnç düzeyleri de saptanmıştır. İzole edilen bu suşların antibiyotik direnç düzeyleri sırasıyla; sefazolin: $\% 69,6$, sefuroksim: $\% 59,4$, nalidiksik asit: $\% 51,7$, amfisilin: $\% 46$, sefotaksim: \%39,1, meropenem: \%31,4, amikasin: \%21,7, eritromisin: \%13 ve kloramfenikol: \%3,3 olarak saptanmıştır. Araştırmamızda antibiyotik ve ağır metal direnç düzeyi yüksek olan iki izolat Vitek-II Kompakt Sistem ile identifiye edilerek Serratia marcencens (\%99) ve Enterococcus avium (\%91) olarak tanımlanmıştır. Ayrıca yüzey suyu örneği izolatlarındaki çoklu antibiyotik direnç değeri (ÇAD) oranının $\% 80,5^{\prime}$ olduğu belirlenmiştir. Sonuç olarak bu çalışmada Gelevera Deresi (Giresun)'nden izole edilen izolatların ticari olarak kullanılan antibiyotiklere ve ağır metallere karşı yüksek düzeyde direnç gösterdiği ve bu durumun içme suyu kaynakları üzerinde antibiyotik ve ă̆ır metal kirliliğinin olduğunu göstermektedir.

$\underline{\text { Anahtar kelimeler: Ağır Metal, Antibiyotik, Direnç, Gelevera Deresi, Giresun. }}$ 


\section{INTRODUCTION}

Water, an essential element for organisms to continue their lives, is one of our most important natural resources. Water is the most basic compound that is difficult to replace for life because it contains all the features related to life in its structure. Deterioration of the quality or balance of water in an environment for various reasons also leads to water pollution. It is assumed that $80 \%$ of all diseases in the developing world are caused by a lack of healthy water and cleaning conditions. More than 5 million people die each year from water pollution and more than half of them are children (Anonymous, 2007). Pathogenic bacteria, viruses, and parasites are among the harmful biological factors that can exist in water and endanger human health (Lawa, 1998). Although the first thought that awakens in our minds about the cause of microbiological pollution in the aquatic environments in question is fecal-based contamination, emergency action plans have been prepared for the 'Antibiotic Resistance', which seems to be the most important problem nowadays, and 'Antibiotic Resistance' has also been added among the reasons to make all people more sensitive about this issue. According to the report published by World Health Organization, medicine has regressed before the antibiotic age in the fight against bacteria and that many antibiotics, most of which are used for therapeutic purposes, do not work effectively, therefore a great disaster awaits in the rest of human life (Anonymous, 2014).

Nowadays, resistance is identified as a major problem in the path of new drug synthesis, reducing antibiotic resistance is a important public health issue in the world. (Hayder \& Aljanaby, 2019). The four main forms of antibiotic resistance develop as; natural resistance (intrinsic, structural), the usage of antibiotics is not because of the resistance but is caused by the bacteria's structural particulars. (Kadhum \& Hasan, 2019). This happen a result of intrinsic resistance, or microorganism which doesn't follow the goal antibiotic structure, or antibiotics which due to its characteristics do not encounter its goal (Waglechner \& Wright, 2017).

Gained resistance; irrespective of resistance development due to change in the genetic features of bacteria, an gained because it is not affected by the antibiotics it was beforehand sensitive to it (Andersson et al., 2020). The source of this form of resistance generally comes from the main chromosome or extrachromosomal structures. (plasmids, transposons, etc.) (Aljanaby \& Aljanaby, 2018).

The main reason for the quick increase in antibiotic resistance is the unconscious take of antibiotics. For this reason, a bacterium becomes resistant to the activity of an antimicrobial drug. As a result of the unconscious prescribing of antibiotics and their systematic application as growth accelerators in animal husbandry, this has worsened over the past decade (Acharya \& Wilson, 2019). On the other hand, aquatic environments have contributed to the formation of antibiotic-resistant bacteria in humans and animals, particularly by the fact that drinking water can be obtained from surface water and antibiotic-resistant genes can enter non-pathogenic water bacteria (Akduman et al., 2020; Baquero et al., 2008; Şahin et al., 2021). The main reason for the growth of antibioticresistant genes in marine and freshwater ecosystems is the improvement of a long-term resistance reservoir (Di Cesare et al., 2015).

Heavy metal-resistant bacteria may develop in aquatic environments due to the presence of metal, mostly caused by anthropogenic activities and environmental factors (Altuğ \& Balkis, 2009; Nadimpalli et al., 2020). Heavy metals can be described as metals with a density large than $5 \mathrm{~g} / \mathrm{cm}^{3}$. Heavy metals are not biodegradable and are considered an environmental pollutant associated with potential toxicity. A few important heavy metals such as iron, nickel, copper, and zinc are necessary for metabolic reaction and very important as trace elements for organisms. Other heavy metals, such as silver, cadmium and mercury, have no biological role in organisms and harmful effects on them even at very low concentrations (Alam et al., 2011).

Heavy metals are elements not dissolving biologically due to their high stability, and therefore they are environmental pollutants that have settled for a long time. They arise from the use of anthropogenic sources such as mines, power plants, smelters as heavy metal sources, as well as pesticides and fertilizers consisting of metal and mud (Zhu et al., 2013). In the world heavy metal pollution is increasing day by day in many developed and growing countries because of rapid industrialization, mining activities, discharge of industrial wastes, long-term use of low-quality water for irrigation, and intensive agricultural practices (Rizvi et al., 2019). Heavy metal resistance frequently exists in bacteria exposed to metals in a variety of habitats and environments. (Pal et al., 2017). Water pollution caused by heavy metals results in the spread of integron-like Gene structures, which are described to play an important role in the development of multiple resistance to antibiotics (Marinescu et al., 2017).

The first step to being taken to protect the natural structure of aquatic environments and ensure that water is healthy and safe for the continuation of the vital activities of people is to determine the pollution standards and the factors that will harm the health of living things. For this reason, this study aims to determine the current antibiotic 
and heavy metal resistance levels of isolates isolated from Gelevera Stream, one of the freshwater resources used for agricultural, drinking, and use purposes in Giresun province located in the Eastern Black Sea Basin, which is one of the most important basins of our country.

\section{MATERIALS AND METHODS}

Study Area: This study was conducted between April 2017 and March 2018 to determine the heavy metal and antibiotic resistance level in the bacterial flora of the Gelevera Stream, located within the borders of the Black Sea Region Giresun (Figure 1). The other name of Gelevera Creek is Özlüce Creek. It is fed by the Karadona, Karaovacık and Çukur creeks that originate from the Balaban Mountains in the province of Gümüşhane, as well as by streams and rivers with small flow rates. Gelevera Stream is $14 \mathrm{~km}$ away from the coastal part and has an estimated surface area of $351 \mathrm{~km}^{2}$. The Gelevera Basin, which has a length of $80 \mathrm{~km}$, is surrounded by Tirebolu, Güçü and Doğankent districts in the East, Yağlidere Basin in the West, Black Sea in the North and Kurdün in the south. Gelevera Creek passes through the villages of Sapmaz, Ericek, and Direkbuku and flows into the sea from the east of Espiye district in Giresun province. It is known that the flow rate of the water is also fast due to the high slope of the stream bed. In addition, Gelevera Stream, one of the most important drinking water resources of Giresun, is under constant pressure from HEPP for energy production, domestic wastes, and quarries (Fig.1).

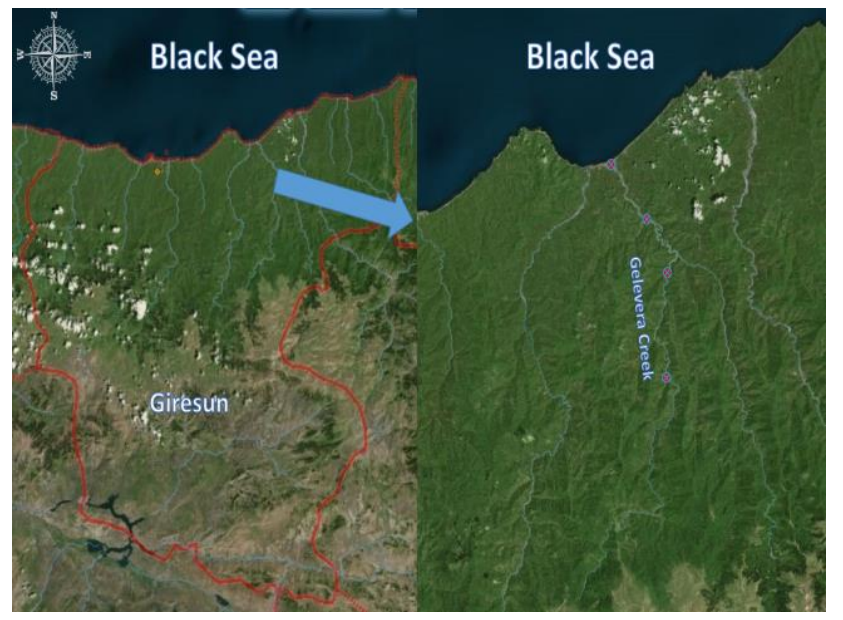

Figure 1. Sampling Area (atlas.gov.tr).

Collection of Surface Water Samples: To ensure the isolation of bacteria, previously sterilized dark glass sample bottles and water samples were taken in a sterile manner $(250 \mathrm{~mL})$ from $20 \mathrm{~cm}$ below the stream surface and brought to the laboratory within 2 hours after being stored with cold chain application (APHA, 1992).
Bacteria Isolation: $\mathrm{Gr}(+)$ and $\mathrm{Gr}(-)$ bacteria isolation was performed from $1 \mathrm{~mL}$ water sample taken from surface water samples using the petri dish spreading technique on Nutrient Agar, PCA Agar, MacConkey Agar, and EMB Agar by serial dilution in sterile distilled water. $1 \mathrm{gr}$ of the sediment samples was homogenized in $9 \mathrm{ml}$ sterile water, and a serial dilution up to $10^{7}$ was prepared in sterile water and plated. After confirming that the isolated bacteria are $\mathrm{Gr}(-)$ and $\mathrm{Gr}(+)$ by Gram staining and some biochemical tests, stock cultures were prepared in Plate Count Agar and Nutrient Agar.

Performing Bacterial Identification and Antibiotic Susceptibility Test: Isolates with high antibiotic and heavy metal resistance were determined. Microorganisms were identified by the Vitek-II (Biomerieux) automatic bacteria identification system. 9 different antimicrobial discs were used (KZ; cefazolin, CXM; cefuroxime, NA; nalidixic acid, AMP; ampicillin, CTX; cefotaxime, MEM; meropenem, AK; amikacin, E; erythromycin and $\mathrm{C}$; chloramphenicol) through the disk diffusion method (Bauer et al., 1966) for determining antibiotic resistance profiles of isolated strains. To enrich the bacteria, it was incubated at $37^{\circ} \mathrm{C}$ for 24 hours by sowing with the help of a loop into the LB broth medium. The incubated samples were placed in Nutrient Agar with the help of sterilized swabs and antibiotic-impregnated discs after the surface was dried with a sterile dispenser. The antibiotic resistance profiles of the bacteria were determined by measuring the zone diameters formed after the 24-hour incubation process.

Multiple Antibiotic Resistance Index (MAR): The multiple antibiotic resistance (MAR) index is calculated by the ratio of the number of antibiotics to which the test organisms are resistant to the total number of antibiotics tested (Ehindimu, 2003). If the isolate has been heavily exposed to antibiotics of human or animal origin, a MAR index value is greater than 0.2 results. However, if the antibiotic was used very rarely or not at all, the MAR index value is observed to be less than or equal to 0.2 (Krumperman, 1985).

Determination of Heavy Metal Resistance: Minimal inhibitory concentrations (MIC) of 4 different heavy metals were calculated for each isolated strain. Heavy metal resistance of bacteria was determined in Müller Hinton Agar medium containing heavy metals $\mathrm{Cu}^{+}$ ${ }^{2}, \mathrm{Cd}^{+2}, \mathrm{~Pb}^{+2}$, and $\mathrm{Mn}^{+2}$ at concentrations of $100,200,400$, 800,1600 , and $3200 \mu \mathrm{g} / \mathrm{mL}$. If the bacterial strain studied can grow in an environment higher than the MIC of the control organism, it is considered resistant. E. coli $\mathrm{K} 12$ standard strain was used as a control organism according to (Table 1). 
Table 1. Heavy Metal Resistance Levels of E. coli K12 (Akinbowale et al., 2007).

\begin{tabular}{lc}
\hline Heavy Metal Name & MIC Value \\
\hline Cadmium & $100 \mu \mathrm{g} / \mathrm{mL}$ \\
Copper & $200 \mu \mathrm{g} / \mathrm{mL}$ \\
Lead & $1600 \mu \mathrm{g} / \mathrm{mL}$ \\
Manganese & $1600 \mu \mathrm{g} / \mathrm{mL}$ \\
\hline
\end{tabular}

\section{RESULTS}

Seasonal change values of heavy metal resistance levels of Gelevera Stream water and sediment samples according to stations; the heavy metal resistivity numbers of 77 isolates were isolated from the first station were determined as $\mathrm{Cd}$ : 60, $\mathrm{Cu}$ : 35, $\mathrm{Mn}:$ 7, and $\mathrm{Pb}: 7$, respectively. Resistant isolates as a percentage were determined as $\mathrm{Cd}$ : 77.9, $\mathrm{Cu}$ : 45.5, Mn: 9.1, and $\mathrm{Pb}$ : 9.1, respectively. Also, 81 isolates isolated from the second station were determined as $\mathrm{Cd}: 71, \mathrm{Cu}: 55, \mathrm{Mn}: 17$, and $\mathrm{Pb}$ : 12, respectively. As a percentage, the number of resistant isolates was determined as $\mathrm{Cd}: 87.7, \mathrm{Cu}: 67.9, \mathrm{Mn}: 21$, and $\mathrm{Pb}$ : 14.8, respectively. Likely, the heavy metal resistance numbers of 84 isolates from the third station are as follows; $\mathrm{Cd}: 66, \mathrm{Cu}: 56, \mathrm{Mn}: 10$, and $\mathrm{Pb}: 9$. As a percentage, the number of resistant isolates was determined as $\mathrm{Cd}$ : 78.6, $\mathrm{Cu}: 66.7, \mathrm{Mn}: 11.9$, and $\mathrm{Pb}: 10.7$, respectively. And, the heavy metal resistance levels of 83 isolates from the fourth station are as follows; $\mathrm{Cd}: 66, \mathrm{Cu}: 60, \mathrm{Mn}: 14$, and $\mathrm{Pb}: 14$ Resistant isolates as a percentage were determined as $\mathrm{Cd}$ : 79.5, $\mathrm{Cu}: 72.3, \mathrm{Mn}: 16.9$, and $\mathrm{Pb}: 16.9$, respectively (Fig. 2).

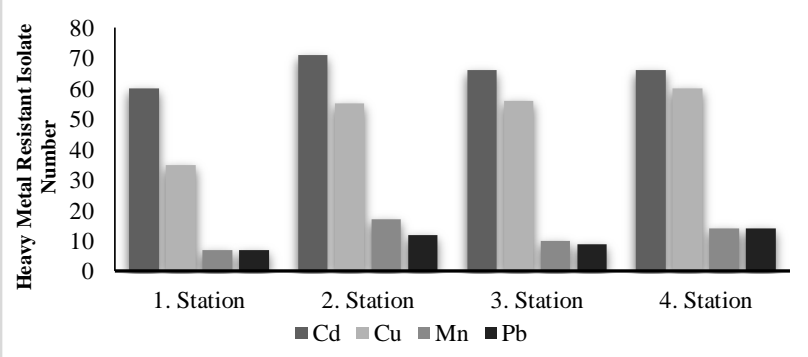

Figure 2. Stational changes value of heavy metal resistance levels.

Seasonal change values of the antibiotic resistance levels of Gelevera Creek water and sediment samples according to stations; antibiotic resistance levels of 11 isolates with high heavy metal resistance at the First Station were determined as follows: KZ: $81.8 \%$, CXM: 63.3\%, NA: 54.5\%, AMP: 54.5\%, MEM: $36.4 \%$, CTX: $33.3 \%$, AK: $18.2 \%$, and E: $9.1 \%$. Also, all isolates were determined of chloramphenicol sensitivity. Heavy metal resistance numbers of isolates with antibiotic resistance were determined as $\mathrm{Cd}$ : $11, \mathrm{Cu}: 5, \mathrm{Mn}: 3$, and $\mathrm{Pb}: 2$, respectively. Resistant isolates as a percentage were determined as $\mathrm{Cd}: 100 \mathrm{Cu}: 45.5 \mathrm{Mn}: 27.3$ and $\mathrm{Pb}$ : 18.2, respectively. Also, antibiotic resistance levels of 33 isolates with high heavy metal resistance in the Second Station were determined as follows: KZ: $54.5 \%$, NA: 51.5\%, AMP: 45.5\%, CXM: 42.4\%, CTX: 24\%, 2, M: 21.2\%, AK: $21.2 \%$, MEM: $15.2 \%$, and C: $3 \%$. Heavy metal resistance numbers of isolates with antibiotic resistance were determined as $\mathrm{Cd}: 29, \mathrm{Cu}: 25, \mathrm{Mn}: 15$, and $\mathrm{Pb}: 10$, respectively. Resistant isolates as a percentage were determined as $\mathrm{Cd}$ : 87.9, $\mathrm{Cu}$ : 75.8, Mn: 45.5, and $\mathrm{Pb}: 30.3$, respectively. Likely, antibiotic resistance levels of 18 isolates with high heavy metal resistance at the Third Station were as follows: KZ: $72.2 \%$, CXM: $66.7 \%$, NA: 55.6\%, AMP: 38.9\%, CTX: 38.9\%, MEM: 38.9\%, AK: 22.2\%, E: $16.7 \%$, and C: $3 \%$ Heavy metal resistance numbers of isolates with antibiotic resistance were determined as $\mathrm{Cd}: 15, \mathrm{Cu}: 8, \mathrm{~Pb}: 7$ and $\mathrm{Mn}$ : 3, respectively. Resistant isolates as a percentage were determined as $\mathrm{Cd}$ : 83.3, $\mathrm{Cu}: 44.4, \mathrm{~Pb}: 38.9$, and $\mathrm{Mn}: 16.7$, respectively. And, antibiotic resistance levels of 20 isolates with high heavy metal resistance at Station Four are KZ: 70\%, CXM: 65\%, CTX: 60\%, AMP: 45.9\%, NA: 45\%, MEM: 35\%, AK: 25\%. C: $10 \%$ and E: $5 \%$. Heavy metal resistance numbers of isolates with antibiotic resistance were determined as $\mathrm{Cd}$ : 17, $\mathrm{Cu}:$ 15, Pb: 9, and Mn: 6, respectively. Resistant isolates as a percentage were determined as $\mathrm{Cd}: 85, \mathrm{Cu}: 75$, $\mathrm{Pb}: 45$, and $\mathrm{Mn}: 30$, respectively.

"C ш

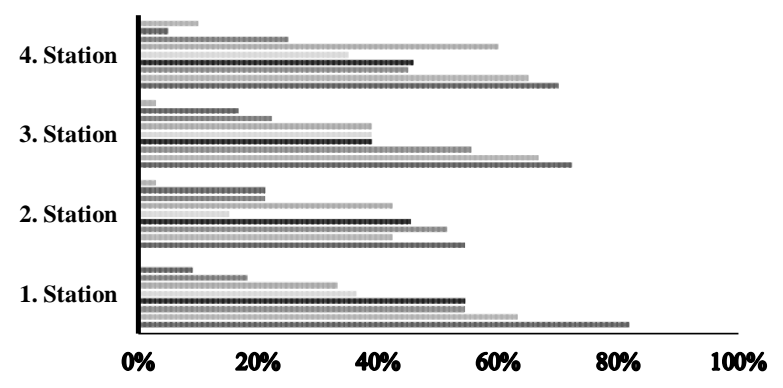

Figure 3. Stational changes value of antibiotic levels (\%).

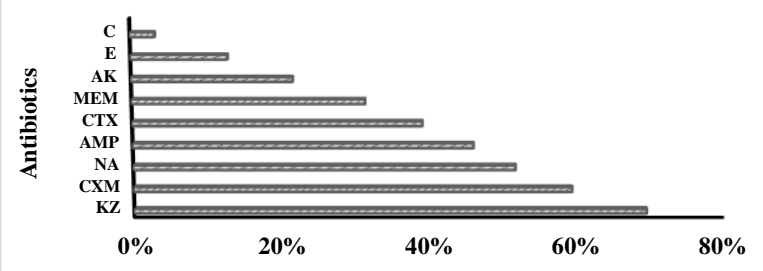

Figure 4. Antibiotic Resistance Levels (\%). 
During the study, resistance to at least 2 antibiotics was detected in 66 of the 82 isolates isolated and it was determined that $80.5 \%$ of the MAR Index reference range was exceeded (Table 2).

Table 2. MAR index value results of the isolates.

\begin{tabular}{lllllll|cccc}
\hline Number of antibiotics & $\mathbf{9}$ & $\mathbf{8}$ & $\mathbf{7}$ & $\mathbf{6}$ & $\mathbf{5}$ & $\mathbf{4}$ & $\mathbf{3}$ & $\mathbf{2} *$ & $\mathbf{1}$ & $\mathbf{0}$ \\
\hline Number of resistant isolates & 1 & 0 & 0 & 6 & 16 & 15 & 16 & 12 & 10 & 6 \\
\hline
\end{tabular}
$\begin{array}{ll}\mathrm{MAR}>0.2 \mathrm{~N}=82 & 66(\% 80.5)\end{array}$

\section{DISCUSSION and CONCLUSION}

When we look at the findings of the studies on antibiotic and heavy metal resistance levels of bacteria isolated from water resources worldwide, India, West Bengal, Kolkata, Dhapa, isolated from municipal waste Bacillus sp. heavy metal tolerant and antibiotic-resistant microorganisms were detected. In the presence of $\mathrm{Cd}^{+2}>$ $\mathrm{Cr}^{+6}>\mathrm{Ni}^{+2}>\mathrm{Co}^{+2}$ metals, respectively, the resistance ratios and antibiotic resistance of the isolates are determined by many factors such as kanamycin ( $30 \mu \mathrm{g} /$ disk), ampicillin (25 $\mu \mathrm{g} /$ disk) and methicillin ( $5 \mu \mathrm{g} /$ disk). It has also been observed to be resistant to antibiotics (Samanta et al., 2012). Resistant bacteria were investigated in sediment and seawater samples taken from the Aegean Sea between 2011 and 2013. All bacteria isolated from sediment samples showed $100 \%$ resistance to rifampicin, sulfonamide, tetracycline and ampicillin. It was noted that $98 \%$ of bacteria were resistant to nitrofurantoin and oxytetracycline, and bacteria isolated from sediment had higher antibiotic and heavy metal resistance than seawater samples. Among the isolates, the highest bacterial metal resistance was reported as $58.3 \%$ against copper, $33.8 \%$ against zinc, $32.1 \%$ against lead, $31 \%$ against chromium and $25.2 \%$ against iron (Altuğ et al., 2020).

Antibiotic and heavy metal resistance of bacteria isolated from different wastewater contaminated areas in Bucharest and its surroundings in Romania are $40 \%$ resistant to amoxicillin-clavulanic acid, 30\% to cefazolin and tetracycline, $25 \%$ were resistant to cefoxitin and ceftazidime, $20 \%$ to ceftriaxone and sulfamethoxazole, that $15 \%$ were resistant to aztreonam, ciprofloxacin, piperacillin and imipenem, $10 \%$ to tobramycin and 5\% to cefotaxime and amikacin respectively. It has been determined that $15 \%$ of the heavy metal resistance ratio of the isolates are resistant to mercury, $40 \%$ to copper, $75 \%$ to chromium and $80 \%$ to zinc, and $100 \%$ of all isolates are resistant to cadmium and aluminum (Marinescu et al., 2017). Antibiogram test of $P$. shigelloides $(\mathrm{n}=182)$ isolated from 3 rivers of South Africa was performed. In this study, freshwater $P$. shigelloides isolates were tested against 24 antibiotics and it was determined that they have multiple resistance against cephalosporins, quinolones, and fluoroquinolones. 13 EUCAST (ERA) and 11 nonrecommended antibiotics (NA), used as first-line agents in the treatment of gastroenteritis and extraintestinal infections, were tested. Resistance to ERAs cefoxitin $37.9 \%$, cefuroxime $35.1 \%$, cefepime $31.8 \%$, ceftriaxone $29.6 \%$, ciprofloxacin $18.1 \%$, trimethoprimsulfamethoxazole $10.4 \%$, piperacillin $8.7 \%$, ertapenem $4.9 \%$, norfloxacin $4.4 \%$, levofloxacin $2.7 \%$, meropenem $1.1 \%$ and imipenem $0.5 \%$. Although isolates have higher resistance $(\geq 36.07)$ to NA's, it has been reported that they are susceptible to amikacin $67.5 \%$, gentamicin $73 \%$, and tetracycline $80.7 \%$ (Ekundayo \& Okoh, 2020). In their study aiming to determine the antibiotic and heavy metal resistance of $S$. aureus associated with animal husbandry, which was first isolated from South African livestock production systems, heavy metal resistance is determined as cadmium $90 \%$, zinc $88 \%$, lead $86 \%$, and copper $84 \%$. When antibiotic resistance was examined, it was reported that $90.8 \%$ of the $S$. aureus isolates were resistant to at least three antibiotics and therefore were classified as multidrugresistant and $98 \%$ of the tested isolates were resistant to penicillin $G$ (Dweba et al., 2019). Compared to the findings of the studies carried out, the findings in our study have some similarities in terms of the isolates in the antibiotic and heavy metal resistance levels. Exposure to antibioticresistant bacteria poses a public health problem as it is directly linked to disease management. There can be several ways of dealing with resistant bacteria. Hospital and city wastewater appear to play an important role in spreading bacteria and antibiotic resistance genes to our environment (Aali et al., 2014).

In terms of determining sea fish 134 isolated Enterobacteriaceae antibiotics and heavy metal resistance levels, the findings indicated that antibiotic resistance levels of; erythromycin: $85 \%$, cefazolin: $79.8 \%$, cefotaxime: $78.3 \%$, cefuroxime axetil: $71.6 \%$, nalidixic acid: $60.4 \%$, ampicillin: 58.9\%, amikacin: $53.7 \%$, tetracycline: $47.7 \%$ and streptomycin: $17.9 \%$. In addition, it was determined that the rate of isolates exceeding the CAA reference value was $88 \%$ and the isolates had a high level of heavy metal resistance (Sipahi et al., 2013). Fecal bacterial density and resistance to antibiotics of a total of 232 Gram-negative bacteria isolated in Küçükçekmece Lagoon (Istanbul) are as follows: ampicillin 76.3\%, amoxicillin-clavulanic acid $36.9 \%$, streptomycin $20.7 \%$, nalidixic acid, and tetracycline $16.8 \%$, ceftazidime $16.4 \%$, chloramphenicol $9.4 \%$, imipenem $6.8 \%$ and amikacin $6.4 \%$ (Sivri et al., 2012). In another study, similar results were acquired by Mercimek Takci et al., (2021) who stated that MAR and MHMR index of 21 E. coli strains isolated from Seve Dam and Konak Pond, Kilis were recorded as 0.187 and 0.202 , respectively. Resistance rates of Enterobacteriaceae isolates isolated from Batlama Creek (Giresun) are reported as follows: ampicillin: 75\%, erythromycin: 64\%, nalidixic acid: $48 \%$, tetracycline: 
39\%, amikacin: 34\%, cefazolin and chloramphenicol: $33 \%$, cefuroxime: $32 \%$, and cefotaxime: $23 \%$. In the study, it was reported that $77 \%$ of the isolates exceeded the MAR reference limit and two isolates were resistant to all antibiotics tested (Akkan, 2017).

Antibiotic resistance profiles were determined as amoxicillin $77.5 \%$, ampicillin $100 \%$, cefazolin $65 \%$, and cefoxitin $65 \%$ in isolates isolated from 6 different drinking water sources open to the public in Kilis (Şahin, 2018). Current antibiotic resistance development of $E$. coli isolated from different stations seasonally for 1 year from the central Batlama Creek of Giresun has been determined as follows: ampicillin $59 \%$, tetracycline $50.8 \%$, nalidixic acid $44.4 \%$, erythromycin $42.9 \%$, chloramphenicol $38.1 \%$, cefazolin $36 \%$, cefuroxime $35.9 \%$, cefotaxime $28.4 \%$. The ratio of multiple antibiotic resistance values (MAR) was reported as $73.28 \%$ (Topkaraoğlu, 2018). In the study conducted to determine the frequency of antibiotic and heavy metal resistance from water samples taken from Lake Sapanca between 2008 and 2010, the highest bacterial resistance among 84 isolates was found to be $90.4 \%$ to vancomycin, $88.1 \%$ to ampicillin, and $64,2 \%$ to amoxicillin-clavulanate. When the resistance was examined, rates varying between $10.7 \%$ and $59.5 \%$ were found against cefuroxime, kanamycin, aztreonam, ceftazidime, cefotaxime, and oxacillin. In terms of heavy metal ions, the highest frequency was recorded as $74.1 \%$ against nickel; and heavy metal resistance against copper, zinc, mercury, and cadmium were $52.3 \%, 46.4 \%, 33.3 \%$, and $26.1 \%$, respectively (Türetken et al., 2019).

The resistance levels of 325 bacteria against 4 different heavy metals were determined after the selective isolation of $\mathrm{Gr}(-)$ and $\mathrm{Gr}(+)$ bacteria. Resistance levels of 325 bacteria isolated in total to $\mathrm{Cd}, \mathrm{Cu}, \mathrm{Pb}$ and $\mathrm{Mn}$ heavy metals were determined as $89.0 \%, 60.16 \%, 33.0 \%, 29.8 \%$ $(\mathrm{Cd}>\mathrm{Cu}>\mathrm{Pb}>\mathrm{Mn})$, respectively. In addition, antibiotic resistance levels of the isolates with high heavy metal resistance levels were determined at each station. The 82 isolates with high resistance against heavy metals, antibiotic resistance levels of these isolated strains are as follows: cefazolin: $69.6 \%$, cefuroxime: $59.4 \%$, nalidixic acid: $51.7 \%$, ampicillin: $46.0 \%$, cefotaxime: $39.1 \%$, meropenem: $31.4 \%$, amikacin: $21.7 \%$, erythromycin: $13.0 \%$, and chloramphenicol: $3.3 \%$. In our study, two isolates with high antibiotic and heavy metal isolate no 55 and 642 showing high resistance were identified by VitekII Compact System and defined as Serratia marcescent (99\%) and Enterococcus avium (91\%). In addition, the rate of multiple antibiotic resistance values (MAR) in surface water sample isolates is $80.5 \%$. As a characteristic member of the Enterobacteriaceae family and supplementary to its competence for survival, S. marcescens characteristically exhibitions a tendency to express antimicrobial resistance.
S. marcescens are uniformly resistant to a great range of antibiotics involving narrow-spectrum-penicillins and cephalosporins, cefuroxime, cephamycins, macrolides, tetracycline, nitrofurantoin, and colistin (Stock et al., 2003). The region around the Sangam region of Allahabad, Uttar Pradesh, India has shown a large variety of microorganisms out of which $S$. marcescens has shown significant antibiotic and heavy metal resistant patterns. To survive these metal stressed terms, microorganisms have developed to withstand the uptake of heavy metal ions. (Nies and Silver, 1995). S. marcescens is ubiquitous and can be found in water, soil, plants, insects, and animals (Abbott, 1999). Distinct strains of Serratia have shown different resistant patterns suggestive of plasmid-borne transfer of resistant genes or pump effluxing systems. But it has been proposed that increasing antibiotic resistance of Gram-negative bacteria is primarily because of mobile genes on plasmids that can easily travel through bacterial populations (Kumarasamy et al., 2010).

In conclusion, this study shows that isolates taken from Gelevera Creek (Giresun) have high resistance to commercially used antibiotics and heavy metals, and this suggests that there is antibiotic and heavy metal pollution on drinking water sources. When compared to the studies in the literature, it is concluded that the antibiotic and heavy metal resistance levels of the bacteria isolated from the Gelevera Course are at a considerable level and the current situation must be checked with a regular monitoring program.

\section{ACKNOWLEDGMENT}

This master's thesis study numbered 629376 prepared by Hakan IŞIK was partially presented at the 1st International Symposium on Technological Sciences and Design (ITESDES, 2018) on 27-29 June 2018, GiresunTurkey. Hakan IŞIK thanks to the council of higher education (YOK) for 100/2000 scholarships..

\section{REFERENCES}

Aali, R., Nikaeen, M., Khanahmad, H. \& Hassanzadeh, A. (2014). Monitoring and comparison of antibiotic-resistant bacteria and their resistance genes in municipal and hospital wastewaters. International Journal of Preventive Medicine. 5, 887-894.

Abbott, S. (1999). Klebsiella, Enterobacter, Citrobacter, and Serratia, p. 475-482. In P.R. Murray, E.J. Baron, M.A. Pfaller, F.C. Tenover, and R.H. Yolken (ed.), Manual of Clinical Microbiology, 7th ed. ASM Press, Washington, DC. 
Acharya, K.P. \& Wilson, R.T. (2019). Antimicrobial resistance in Nepal. Frontiers in medicine, $\mathbf{6}, 105$. DOI: 10.3389 /fmed.2019.00105

Aiking, H., Stinamn, A., Van-Ganderen, C., VanHeerikhuizen, H. \& Vant-Riet, J. (1984). Inorganic phosphate accumulation and cadmium detoxification in Klebsiella aerogenes NCTC 418 growing in continuous culture. Applied and Environmental Microbiology, 47, 374-377. DOI: 10.1128/aem.47.2.374-377.1984

Akduman, S., Demirbağ, M. \& Sivri, N. (2020). Türkiye'de bakteriyolojik su kalitesi konusunda yapılan bilimsel araştırmaların bibliyometrik analizi (1999-2019). Journal of Anatolian Environmental and Animal Sciences, 5(3), 425432. DOI: $10.35229 /$ jaes. 779012

Akkan, T. (2017). Antibiotic resistance case study: Enterobacteriaceae isolated from Batlama Creek in Giresun, Turkey. Turkish Journal of Agriculture-Food Science and Technology, 5(8), 969-972. DOI: 10.24925/turjaf.v5i8.969972.1262

Alam, M.Z., Ahmad, S. \& Malik, A. (2011). Prevalence of heavy metal resistance in bacteria isolated from tannery effluents and affected soil, Environmental Monitoring and Assessment, 178(1), 281-291. DOI: $10.1007 / \mathrm{s} 10661-010-1689-8$

Alanso, A., Sanchez, P. \& Martinez, J.L. (2001). Environmental selection of antibiotic resistance genes. Environmental Microbiology, 3, 1-9. DOI: 10.1046/j.1462-2920.2001.00161.x

Aljanaby, A.A.J. \& Aljanaby, I.A.J. (2018). Prevalence of aerobic pathogenic bacteria isolated from patients with burn infection and their antimicrobial susceptibility patterns in Al-Najaf City, Iraq-a three-year cross-sectional study. F1000Research, 7(1157), 1157. DOI: 10.12688/f1000research.15088.1

Altuğ, G. \& Balkış, N. (2009). Levels of some toxic elements and frequency of bacterial heavy metal resistance in sediment and seawater. Environmental monitoring and evaluation., 149(1), 61-69. DOI: 10.1007/s10661-008-0183-Z

Altuğ, G., Çardak, M., Türetken, P. S. Ç., Kalkan, S., \& Gürün, S. (2020). Antibiotic and heavy metal resistant bacteria isolated from Aegean Sea water and sediment in Güllük Bay, Turkey. Johnson Matthey Technology Review. DOI: 10.1595/205651320X15953337767424

Andersson, D.I., Balaban, N.Q., Baquero, F., Courvalin, P., Glaser, P., Gophna, U. \& Tønjum, T. (2020). Antibiotic resistance: turning evolutionary principles into clinical reality. FEMS Microbiology Reviews. 44(2), 171-188. DOI: 10.1093/femsre/fuaa001

Anonim, (2007). Water Quality Outlook. UNEP Global Environment Monitoring System (GEMS)/Water Programme Office, http://esa.un.org/iys/docs/san_lib_docs/water_qu ality_outlook.pdf.
Anonim, (2014). World Health Organization. Antimicrobial resistance global report on surveillance. France. http://www.who.int/drugresistance/documents/su rveillancereport/en/ (09.12.2019).

APHA, (1992). Standard Methods for the Examination of Water and Wastewater, 18th ed. APHA, Washington, DC. https://law.resource.org/pub/us/cfr/ibr/002/apha. method.9221.1992.pdf (09.12.2019).

Baquero, F., Martínez, J.L. \& Cantó, R. (2008). Antibiotics and antibiotic resistance in water environments. Current Opinion in Biotechnology, 19, 260-265. DOI: 10.1016/j.copbio.2008.05.06

Bauer, A.W., Kirby, W.M.M., Sherris, J.C. \& Turck, M. (1966). Antibiotic susceptibility testing by a standardized single disk method. Am. J. Clin. Path., 45, 493-496. DOI: ASM/media/docs/105bauer.pdf

Di Cesare, A., Eckert, E.M., Teruggi, A., Fontaneto, D., Bertoni, R., Callieri, C. \& Corno, G. (2015). Constitutive presence of antibiotic resistance genes within the bacterial community of a large subalpine lake. Molecular Ecology, 24, 38883900. DOI: $10.1111 / \mathrm{mec} .13293$

Dweba, C.C., Zishiri, O.T. \& El Zowalaty, M.E. (2019). Isolation and molecular identification of virulence, antimicrobial and heavy metal resistance genes in livestock associated methicillin-resistant Staphylococcus aureus. Pathogens, $\quad 8(2), \quad 79 . \quad$ DOI: 10.3390/pathogens 8020079

Ekundayo, T.C. \& Okoh, A.I. (2020). Antimicrobial resistance in freshwater Plesiomonas shigelloides isolates: Implications for environmental pollution and risk assessment, Environmental Pollution, 257, $113493 . \quad$ DOI: 10.1016/j.envpol.2019.113493

Hassen, A., Saidi, N., Cherif, M. \& Boudabous, A. (1998). Resistance of Environmental bacteria to heavy metals. Bioresource Technology, 64(1), 715. DOI: $10.1016 / \mathrm{S} 0960-8524(97) 00161-2$

Hayder, T. \& Aljanaby, A.A.J. (2019). Genotypic characterization of antimicrobial resistanceassociated genes in citrobacter freundii ssolated from patients with urinary tract infection in AlNajaf Governorate-Iraq. On Line Journal of Biological Sciences, 19(2), 132 145. DOI: 10.3844/ojbsci.2019.132.145

Kadhum, H.A. \& Hasan, T.H. (2019). The study of Bacillus subtils antimicrobial activity on some of the pathological isolates. International Journal of Drug Delivery Technology, 9(02), 193-196. DOI: 10.25258/ijddt.9.2.12

Kır, I., Tekin Ozan, S. \& Tuncay, Y. (2007). The seasonal variations of some heavy metals in Kovada Lake's water and sediment. Ege University, Journal of Fisheries, 24(1-2), 155158.

Krumperman, P.H. (1985). Multiple antibiotic resistance indexing of Escherichia coli to identify high-risk 
sources of fecal contamination of foods. Applied and Environmental Microbiology, 46, 165-170. DOI: 10.1128/aem.46.1.165-170.1983

Kumarasamy, K.K., Toleman, M.A., Walsh, T.R., Bagaria, J., Butt, F. \& et al. (2010). Emergence of a new antibiotic resistance mechanism in India, Pakistan, and the UK: a molecular, biological, and epidemiological study. Lancet Infect. Dis., 10, 597-602. DOI: 10.1016/S1473-3099(10)70143-2

Lawa, (1998). Bewertung der Wasserbeschaffenheit von Fliesgewa"ssern in der Bundesrepublik Deutschland echemische Gewa"ssergu"teklassifikation. Berlin: Kulturbuchverlag Berlin GmbH, 51-54pp.

Marinescu, F., Chifiriuc, M.C., Marutescu, L., Ilie, M., Savin, I., Anghel, A.M. \& Marcu, E. (2017). Prevalence of heavy metal and antibiotic resistance in bacterial isolates from wastewater and receiving aquatic environments. Biointerface Research in Applied Chemistry, 7(5), 2140-2144.

Mercimek Takci, H.A., Toplar, S. \& Sumengen Ozdenefe, M. (2021). Antibiotic and heavy metal resistance of Escherichia coli strains isolated from the Seve Dam, and Konak Pond, Kilis, Turkey. Acta Aquatica Turcica, 17(2), 290-297. DOI: 10.22392/actaquatr.801564

Nadimpalli, M.L., Marks, S.J., Montealegre, M.C., Gilman, R.H., Pajuelo, M.J., Saito, M., Tsukayama, P., Njenga, S.M., Kiiru, J., Swarthout, J., Islam, M.A., Julian, T.R. \& Pickering, A.J. (2020). Nat. Microbiol, 5(6), 787. https://doi.org/10.1038/s41564-020-0722-0

Nies, D.H. \& Silver, S. (1995). Ion efflux systems involved in bacterial metal resistances. Journal of Industrial Microbiology, 14(2), 186-199.

Pal, C., Asiani, K., Arya, S., Rensing, C., Stekel, D.J., Larsson, D.G.J. \& Hobman, J.L. (2017). Metal resistance and its association with antibiotic resistance. Advances in Microbial Physiology, 70, 261-313. DOI: 10.1016/bs.ampbs.2017.02.001

Rizvi, A., Ahmed, B., Zaidi, A. \& Khan, M.S. (2019). Heavy metal mediated phytotoxic impact on winter wheat: oxidative stress and microbial management of toxicity by Bacillus subtilis BM2. Royale Society of Chemistry Advances 9(11), 6125-6142. DOI: 10.1039/C9RA00333A

Sahin, F. (2018). Determination of Fecal Coliform level and multiple antibiotic resistance in Kilis drinking water sources. Kilis 7 Aralik University, Graduate School of Natural and Applied Sciences, Master Thesis, 44 p. [inTurkish]

Samanta, A., Bera, P., Khatun, M., Sinha, C., Pal, P., Lalee, A. \& Mandal, A. (2012). An investigation on heavy metal tolerance and antibiotic resistance properties of bacterial strain Bacillus sp. isolated from municipal waste, Journal of Microbiology and Biotechnology Research, 2(1), 178-189.

Sipahi, N., Mutlu, C. \& Akkan, T. (2013). Antıbiotıc And Heavy Metal Resistance Levels Of Enterobacteriaceae Isolated From Retail Fishes İn
Giresun, The Journal of Food, 38(6), 343-349. DOI: $10.5505 /$ gida.2013.55264

Sivri, N., Sandalli, C., Ozgumus, O.B., Colakoglu, F. \& Dogan, D. (2012). Antibiotic resistance profiles of enteric bacteria isolated from Kucukcekmece Lagoon (Istanbul-Turkey). Turkish Journal of Fisheries and Aquatic Sciences, 12(3), 699-707. DOI: 10.4194/1303-2712-v12_3_19

Stock, I., Grueger, T. \& Wiedemann, B. (2003). Natural antibiotic susceptibility of strains of Serratia marcescens and the $S$. liquefaciens complex: $S$. liquefaciens sensu stricto, $S$. proteamaculans and S. grimesii. Int J Antimicrob Agents. 22, 35-47. DOI: 10.1016/S0924-8579(02)00163-2

Şahin, S., Sivri, N., Akpinar, I., Çinçin, Z.B. \& Sönmez, V.Z. (2021). A comprehensive bibliometric overview: antibiotic resistance and Escherichia coli in natural water. Environ. Sci. Pollut. Res., 28, 32256-32263. DOI: 10.1007/s11356-02114084-1

Topkaraoglu, T. (2018). Determination of Antibiotic Resistance Levels of Escherichia coli Isolates Obtained from Freshwater Sources: Batlama Creek, Giresun. Master's Thesis, Giresun University, Graduate School of Natural and Applied Sciences, 34p.

Turetken, P.S.C., Altug, G., Cardak, M. \& Gunes, K. (2019). Bacteriological quality, heavy metal and antibiotic resistance in Sapanca Lake, Turkey. Environmental Monitoring and Assessment, 191(7), 469. DOI: 10.1007/s10661-019-7588-8

Waglechner, N. \& Wright, G.D. (2017). Antibiotic resistance: it's bad, but why isn't it worse? BMC Biology, 15(1), 1-8. DOI: 10.1186/s12915-0170423-1

Zhu, Y.G., Johnson, T.A., Su, J.Q., Qiao, M., Guo, G.X., Stedtfeld, R.D., Hashsham, S.A. \& Tiedje, J.M. (2013) Diverse and abundant antibiotic resistance genes in Chinese swine farms. Proc. Natl. Acad. Sci. USA, 110(9), 3435-3440. DOI: 10.1073/pnas. 1222743110 